\title{
Oral Lesions in Elderly Patients in Referral Centers for Oral Lesions of Bahia
}

\author{
Sarah Souza ${ }^{1}$ Técia Alves ${ }^{1}$ Jean Santos ${ }^{2}$ Márcio Oliveira ${ }^{1}$ \\ ${ }^{1}$ Health Department, UEFS, Feira de Santana, Brazil \\ ${ }^{2}$ Health Department, UFBA, Salvador, Brazil \\ Address for correspondence Márcio Oliveira, MD, PhD, Department of \\ Saúde, UEFS, AvTransnodetina, sn Feira de Santana 44075115, Brazil \\ (e-mail: marciopatologiaoral@gmail.com).
}

Int Arch Otorhinolaryngol 2015;19:279-285.

\begin{abstract}
Introduction The aging population phenomenon is occurring on a global scale; aging affects all of the structures of organisms, including the oral cavity.

Objective To estimate the frequency of oral lesions, according to the clinical and histopathologic diagnoses, and to describe the sociodemographic profile of the elderly treated at the referral centers of oral lesions of public universities in Bahia, Brazil.

Methods A descriptive epidemiologic study with transverse characteristics was conducted with elderly patients between August 2010 and January 2012. A form was used to collect data. The descriptive analysis consisted of calculating the simple and relative frequencies of sociodemographic variables and oral lesions.

Keywords

- epidemiology

- mouth diseases

- elderly

- mouth mucosa

- oral lesions

- diagnosis oral

Results The population was predominantly black women, and the minority of elderly people were retired. Fibroid $(13 \%)$ and squamous cell carcinoma $(145 \%)$ were more prevalent clinical diagnoses, with squamous cell carcinoma (30.7\%) and fibrous hyperplasia more prevalent histopathologic diagnoses.

Conclusion A prevention policy needs to be implemented to reduce new cases of oral lesions in Bahia, Brazil and to aid in early diagnosis and appropriate treatment of oral lesions.
\end{abstract}

\section{Introduction}

The aging population poses one of the greatest challenges to contemporary public health, especially in developing countries, where this phenomenon occurs is an environment of poverty and great social inequality. ${ }^{1}$ In dentistry, one concern is the maintenance of oral health of elderly patients, who are subject to the influence of a series of factors that make them susceptible to various diseases, not only in the teeth but also in the different structures that compose the stomatognathic system. ${ }^{2,3}$

There are few studies in the literature regarding the prevention of oral and maxillofacial lesions in elderly subjects, as many articles relate the health status of the elderly with emphasis on caries, periodontal disease, poor hygiene, and tooth loss, ${ }^{1-4}$ without focus on oral lesions, which does not allow a broad vision of the occurrence of diseases. The development of descriptive epidemiologic studies in dentistry is fundamental for the characterization of a population with respect to oral health conditions and to help design assistance and educational programs directed toward a certain age group, thereby improving the quality of life of this population.

Therefore, the aim of this study was to estimate the frequency of oral lesions, according to clinicohistopathologic diagnosis, and to describe the sociodemographic profile of the elderly cared for at the referral centers for oral lesions of public universities in Bahia, Brazil.

\section{Materials and Methods}

A descriptive, cross-sectional, exploratory, census-based epidemiologic study was conducted among the elderly patients received

August 21, 2014

accepted

April 20, 2015

published online

July 17, 2015
DOI http://dx.doi.org/

10.1055/s-0035-1554727. ISSN 1809-9777.
Copyright $\odot 2015$ by Thieme Publicações License terms Ltda, Rio de Janeiro, Brazil 
receiving care at the Reference Center for Oral Lesions in interior city of Bahia (BA1) and at the Surgical Pathology Laboratory in capital of Bahia (BA2) in the period from January 2002 to August 2010. The research project was submitted to the Research Ethics Committee in Bahia, Brazil, which granted approval to conduct the research under Protocol No. 022/2011. The authors declare there was no conflict of interests in this research.

The study population consisted of 683 elderly patients at BA1 and 296 at BA2. Individuals aged 60 years or older who had at least one oral lesion were considered eligible for the study. Individuals were excluded from the study if their dental records and biopsy reports had not been filled out properly or were illegible.

A validated form was used to collect data, and the data and the information contained in the biopsy reports/dental records were transcribed. Possible study variables included sociodemographic conditions (sex, age, race/ethnicity, profession, marital status, schooling, place of residence); clinical suspicion; histopathologic diagnosis; localization and clinical characteristics of the lesion; consumption of tobacco, alcoholic beverages, alcoholic beverages and tobacco together; abandonment of smoking and alcoholism; use and type of dental prosthesis; and trauma caused by dental prosthesis. It was only possible to collect data with reference to lifestyle and use of dental prosthesis from the dental record charts, this type of information was missing from the biopsy reports.

After double digitation of the database, statistical analysis was performed by means of the software program $R$ ( $R$ Foundation for Statistical Computing, Vienna). ${ }^{5}$ The descriptive analysis consisted of calculating the simple and relative frequencies of the sociodemographic variables and of the oral lesions, according to the clinicohistopathologic diagnosis. In this study, only descriptive statistical techniques were used (that is, no tests of statistical analytical inference were performed, because no samples were removed).

Oral lesions were divided into three groups: non-neoplastic lesions, benign neoplastic lesions, and malignant neoplastic lesions, in accordance with the World Health Organization (WHO) classification. ${ }^{6}$ Therefore, the frequencies of these groups of lesions were verified in the studied population for clinical suspicion and for histopathologic diagnosis.

In Bahia, there are three dentistry courses at public universities; however, in only two are there reference centers for oral lesions, which are consolidated with higher learning institutions (BA1 and BA2) and which provide diagnostic services, treatment, and health promotion free of charge to the Bahia population. These centers are also the teaching institutions for future professionals in the health area, and professional are available to patients full-time.

\section{Results}

\section{Sociodemographic Profile}

At BA1, 683 lesions in elderly patients were identified, with 447 being in women and 236 in men (1.9:1). There was predominance of ages ranging between 69 and 100 years (52.7\%), and the mean age was 70.12 years (standard devia- tion $[S D]=7.88)$. Over half the elderly patients $(55.1 \%)$ did not have companions. Using the classification proposed by the IBGE (Brazilian institute for geography and statistics) for race/ethnicity, 190 (31.1\%) individuals were found to be mixed race, 164 (26.8\%) white, 256 (41.9\%) black, and 1 (0.2\%) Asian.

Occupationally, $33.6 \%$ of the sample were retired, $26.7 \%$ were urban workers (with greater emphasis on housewife and domestic professions), and 39.7\% were rural workers.

The majority of the subjects were illiterate (39.5\%) and had incomplete primary schooling (37.2\%). Of the patients, 506 (76.4\%) related that they lived in municipalities surrounding the BA1 installations (-Table $\mathbf{1}$ ).

The information about smoking an alcoholism was not filled out in only two record charts; 143 (21\%) were smokers only, 48 (7\%) consumed alcohol only, 262 (38.5\%) were smokers and consumed alcohol, and 228 (33.5\%) did not use either of the two substances.

No information was found in 14 (2.1\%) record charts regarding the use of dental prosthesis, and 340 (50.8\%) of the elderly patients made use of some type of denture, but with reports of trauma in 197 (70.9\%). The type of denture most frequently identified in these patients was the complete type (73.3\%), followed by the removable partial denture (17\%).

Information was lost about the following variables: marital status, race/ethnicity, occupation, schooling, place of residence, alcohol and tobacco consumption, and use and type of dental prosthesis.

At BA2, 305 biopsy reports were collected; however, 9 were in common with those of BA1. The clinical exam was performed in the latter institution and sent to the former only to obtain the histopathologic results of the biopsies up to the middle of 2006. Therefore, BA2 was excluded from these charts to prevent duplication of data.

The number of elderly patients eligible for the study at BA2 totaled 296, 194 women and 102 men (1.9:1). Predominance was observed of the younger age groups (60 to 68 years: $57.1 \%)$, and the mean age was 68.73 years $(S D=6.74)$. Of the patients, $102(41.5 \%)$ were married, $76(30.9 \%)$ were single, 4 (1.63\%) were separated, and 64 (26\%) were widowed. The majority identified as being black (47.6\%).

Occupationally, 85 (35.1\%) were retired, 132 (54.5\%) were urban workers (with greater emphasis on housewife and domestic professions), and 25 (10.3\%) were rural workers. From the data with reference to place of residence, $64.3 \%$ of the elderly came from surrounding cities to the reference center for oral lesions of BA2 (-Table 1 ).

No information was obtained about schooling and lifestyle (alcohol and tobacco consumption, use of dental prosthesis) on the biopsy reports. Information was lost about the following variables: marital status, patients' race/ethnicity, and place of residence. However, the latter variable had the highest losses (85.8\%), for which only 42 responses were obtained, 26 of which were from women.

\section{Characteristics of Oral Lesions}

Using the WHO (2005) classification and by means of clinical exam, at BA1, non-neoplastic lesions were identified in 318 
Table 1 Sociodemographic characteristics of elderly patients seen at referral centers for oral lesions in public universities of Bahia (BA1 and BA2) from January 2002 to August 2010

\begin{tabular}{|c|c|c|c|c|}
\hline \multirow[t]{2}{*}{ Variable } & \multicolumn{2}{|c|}{ BA1 $(n=683)$} & \multicolumn{2}{|c|}{ BA2 $(n=296)$} \\
\hline & $n$ & $\%$ & $n$ & $\%$ \\
\hline $\begin{array}{l}\text { Sex } \\
\text { Male } \\
\text { Female }\end{array}$ & $\begin{array}{l}236 \\
447\end{array}$ & $\begin{array}{l}34.6 \\
65.4\end{array}$ & $\begin{array}{l}102 \\
194\end{array}$ & $\begin{array}{l}34.5 \\
65.5\end{array}$ \\
\hline $\begin{array}{l}\text { Age }(y) \\
60-68 \\
69-100\end{array}$ & $\begin{array}{l}323 \\
360\end{array}$ & $\begin{array}{l}47.3 \\
52.7\end{array}$ & $\begin{array}{l}169 \\
127\end{array}$ & $\begin{array}{l}57.1 \\
42.9\end{array}$ \\
\hline $\begin{array}{l}\text { Marital status } \\
\text { Single } \\
\text { Married } \\
\text { Separated } \\
\text { Widowed }\end{array}$ & $\begin{array}{l}119 \\
302 \\
25 \\
227\end{array}$ & $\begin{array}{l}17.7 \\
44.9 \\
3.7 \\
33.7\end{array}$ & $\begin{array}{l}76 \\
102 \\
04 \\
64\end{array}$ & $\begin{array}{l}30.9 \\
41.5 \\
1.6 \\
26\end{array}$ \\
\hline $\begin{array}{l}\text { Race/ethnicity } \\
\text { Mixed race } \\
\text { White } \\
\text { Black } \\
\text { Asian }\end{array}$ & $\begin{array}{l}190 \\
164 \\
256 \\
01\end{array}$ & $\begin{array}{l}31.1 \\
26.8 \\
41.9 \\
0.2\end{array}$ & $\begin{array}{l}89 \\
43 \\
120 \\
0\end{array}$ & $\begin{array}{l}35.3 \\
17.1 \\
47.6 \\
0\end{array}$ \\
\hline $\begin{array}{l}\text { Occupation } \\
\text { Retired } \\
\text { Rural worker } \\
\text { Urban worker }\end{array}$ & $\begin{array}{l}215 \\
254 \\
171\end{array}$ & $\begin{array}{l}33.6 \\
39.7 \\
26.7\end{array}$ & $\begin{array}{l}85 \\
25 \\
132\end{array}$ & $\begin{array}{l}35.1 \\
10.3 \\
54.5\end{array}$ \\
\hline $\begin{array}{l}\text { Schooling }^{\mathrm{a}} \\
\text { Primary schooling incomplete } \\
\text { Primary schooling complete } \\
\text { High schooling incomplete } \\
\text { High schooling complete } \\
\text { College education incomplete } \\
\text { College education complete } \\
\text { Illiterate }\end{array}$ & $\begin{array}{l}223 \\
67 \\
22 \\
43 \\
01 \\
07 \\
237\end{array}$ & $\begin{array}{l}37.2 \\
11.2 \\
3.7 \\
7.2 \\
0.2 \\
1.2 \\
39.5\end{array}$ & $\mathrm{NC}$ & $\mathrm{NC}$ \\
\hline $\begin{array}{l}\text { Place of residence }^{a} \\
\text { In the same place as the center of reference } \\
\text { Municipality surrounding the center of reference }\end{array}$ & $\begin{array}{l}157 \\
506\end{array}$ & $\begin{array}{l}23.7 \\
73.3\end{array}$ & $\begin{array}{l}15 \\
27\end{array}$ & $\begin{array}{l}35.7 \\
64.3\end{array}$ \\
\hline
\end{tabular}

${ }^{a}$ Variable with missing data.

Abbreviations: BA1, Reference Center for Oral Lesions in interior city of Bahia; BA2, Surgical Pathology Laboratory in capital of Bahia; NC, data not collected.

elderly patients (51.8\%). Among the oral lesions identified, squamous cell carcinoma was the most prevalent clinical suspicion (14.5\%), followed by leukoplakia (8.8\%), hemangioma (8.1\%), fibroma (7.3\%), and prosthetic stomatitis (6.7\%), as shown in -Table 2. Of the record charts, 614 were duly filled out with identification of a supposed oral lesion and 69 record charts contained information about changes in normality of the oral mucosa.

However, at BA2, non-neoplastic oral diseases were identified by clinical exam in 187 (67.3\%) biopsy reports, and malignant neoplasias were suspected in $10.8 \%$ of the biopsy reports. Among the oral lesions characterized at this reference center by clinical suspicion, fibroma was the most prevalent (13\%), followed by fibrous hyperplasia (10.2\%), squamous cell carcinoma (10.2\%), and leukoplakia (6.7\%; - Table 2). By the findings of the clinical exam, the prevalence of $32.7 \%$ of neoplastic lesions was identified.

When analyzing the findings of the histopathologic exam, at BA1 194 elderly patients had biopsies, but there was no record of the biopsy result on the records of 2 of the patients. Of the cases diagnosed, 83 (44.1\%) were not neoplasias and 68 (36.2\%) were malignant neoplasias. - Table 3 shows that there was a prevalence of $30.7 \%$ of cases of squamous cell carcinoma, followed by hyperkeratosis (10.4\%), fibrous hyperplasia (7.3\%), and hemangioma (6.8\%). In the elderly population of BA1, the prevalence of oral cancer was $36.2 \%$ per histopathologic exam.

At BA2, benign neoplastic lesions were found in 44 (16.2\%) biopsy reports and malignant neoplastic lesions were present in 40 biopsy reports. There were 24 descriptive and/or inconclusive histopathologic results. Fibrous hyperplasia was the most prevalent oral lesion (24\%), followed by squamous cell carcinoma (8.8\%), hyperkeratosis (6.8\%), and fibroma (5.1\%; - Table 3 ). The prevalence of nonneoplastic diseases was $69.1 \%$, diagnosed in 188 biopsy reports. In the elderly population at BA2, the prevalence of oral cancer was $14.7 \%$, proved by the histopathologic exam. 
Table 2 Frequencies of the most prevalent oral lesions according to clinical suspicion in the elderly patients treated in referral centers for oral lesions in public universities of Bahia (BA1 and BA2) from January 2002 to August 2010

\begin{tabular}{|l|l|l|l|l|}
\hline \multirow{2}{*}{ Oral lesion } & \multicolumn{2}{l|}{\begin{tabular}{l}
\multicolumn{2}{l|}{ BA1 } \\
$(\boldsymbol{n}=\mathbf{6 1 4})$
\end{tabular}} & \multicolumn{2}{l|}{$\begin{array}{l}\text { BA2 } \\
(\boldsymbol{n}=\mathbf{2 8 4})\end{array}$} \\
\cline { 2 - 5 } & $\boldsymbol{n}$ & $\%$ & $\boldsymbol{n}$ & \multicolumn{1}{c|}{$\%$} \\
\hline Oral candidiasis & 29 & 4.7 & 0 & 0 \\
\hline Squamous cell carcinoma & 89 & 14.5 & 29 & 10.2 \\
\hline Prosthetic stomatitis & 41 & 6.7 & 0 & 0 \\
\hline Fibroma & 45 & 7.3 & 37 & 13.0 \\
\hline Pyogenic granuloma & 12 & 2.0 & 13 & 4.6 \\
\hline Hemangioma & 50 & 8.1 & 1 & 0.4 \\
\hline Fibrous hyperplasia & 36 & 5.9 & 29 & 10.2 \\
\hline Leukoplakia & 54 & 8.8 & 19 & 6.7 \\
\hline Lichen planus & 16 & 2.6 & 6 & 2.1 \\
\hline Mucocele & 17 & 2.8 & 5 & 1.8 \\
\hline Actinic cheilitis & 31 & 5.0 & 1 & 0.4 \\
\hline Traumatic ulcer & 16 & 2.6 & 2 & 0.7 \\
\hline
\end{tabular}

Abbreviations: BA1, Reference Center for Oral Lesions in interior city of Bahia; BA2, Surgical Pathology Laboratory in capital of Bahia.

For identification of the anatomic location of the lesion, at BA1 the charts of only 23 individuals did not contain this information. The most prevalent location of the oral lesion was the palate (23.6\%), jugal mucosa (15.6\%), lip (14.7\%), tongue (13\%), and alveolar ridge (10.2\%). At BA2, only 8 biopsy reports did not contain identification of the oral lesion

Table 3 Frequencies of the most prevalent oral lesions according to histopathologic results in elderly patients treated in referral centers for oral lesions in public universities of Bahia (BA1 and BA2) from January 2002 to August 2010

\begin{tabular}{|l|l|l|l|l|}
\hline \multirow{2}{*}{ Oral lesion } & \multicolumn{2}{l|}{$\begin{array}{l}\text { BA1 } \\
(\boldsymbol{n}=\mathbf{1 8 8})\end{array}$} & \multicolumn{2}{l|}{$\begin{array}{l}\text { BA2 } \\
(\boldsymbol{n}=\mathbf{2 9 6})\end{array}$} \\
\cline { 2 - 5 } & $\boldsymbol{n}$ & $\%$ & $\boldsymbol{n}$ & $\%$ \\
\hline Squamous cell carcinoma & 59 & 30.7 & 26 & 8.8 \\
\hline Fibroma & 5 & 2.6 & 15 & 5.1 \\
\hline Pyogenic granuloma & 5 & 2.6 & 7 & 2.4 \\
\hline Hemangioma & 13 & 6.8 & 1 & 0.3 \\
\hline Hyperkeratosis & 20 & 10.4 & 20 & 6.8 \\
\hline Fibrous hyperplasia & 14 & 7.3 & 71 & 24.0 \\
\hline Lichen planus & 2 & 1.0 & 3 & 1.0 \\
\hline Mucocele & 3 & 1.6 & 1 & 0.3 \\
\hline Inflammatory process & 4 & 2.1 & 14 & 4.8 \\
\hline Actinic cheilitis & 3 & 1.6 & 2 & 0.7 \\
\hline Descriptive report & 4 & 2.1 & 23 & 7.8 \\
\hline
\end{tabular}

Abbreviations: BA1, Reference Center for Oral Lesions in interior city of Bahia; BA2, Surgical Pathology Laboratory in capital of Bahia.
Table 4 Frequencies of the anatomical location of oral lesions in elderly patients treated in referral centers for oral lesions in public universities of Bahia (BA1 and BA2) from January 2002 to August 2010

\begin{tabular}{|l|l|l|l|l|}
\hline \multirow{2}{*}{$\begin{array}{l}\text { Anatomic location } \\
\text { of oral lesions }\end{array}$} & \multicolumn{2}{l|}{$\begin{array}{l}\text { BA1 } \\
(\boldsymbol{n}=\mathbf{6 5 3})\end{array}$} & \multicolumn{2}{l|}{$\begin{array}{l}\text { BA2 } \\
(\boldsymbol{n}=\mathbf{2 8 9})\end{array}$} \\
\cline { 2 - 5 } & $\boldsymbol{n}$ & $\%$ & $\boldsymbol{n}$ & $\%$ \\
\hline Labial commissure & 24 & 3.6 & 1 & 0.3 \\
\hline Lip & 97 & 14.7 & 25 & 8.7 \\
\hline Tongue & 86 & 13 & 25 & 8.7 \\
\hline Mandible & 15 & 2.3 & 40 & 13.8 \\
\hline Jugal mucosa & 103 & 15.6 & 45 & 15.6 \\
\hline Palate & 156 & 23.6 & 28 & 9.7 \\
\hline Alveolar ridge & 67 & 10.2 & 52 & 18 \\
\hline Floor of the mouth & 38 & 5.8 & 9 & 3.1 \\
\hline
\end{tabular}

Abbreviations: BA1, Reference Center for Oral Lesions in interior city of Bahia; BA2, Surgical Pathology Laboratory in capital of Bahia.

location. At this institution, the alveolar ridge was the most prevalent location for oral lesions in 52 (18\%) biopsy reports, followed by the jugal mucosa (15.6\%), mandible (13.8\%), palate (9.7\%), lip (8.7\%), and tongue (8.7\%; - Table 4$)$.

\section{Discussion}

Epidemiologic studies may promote an important view for the understanding of the prevalence, extent, and severity of oral diseases in the aging population. Nevertheless, there are still a limited number of studies in the literature addressing diagnosis and identification of the prevalence of lesions in the oral mucosa of the elderly population ${ }^{3,4}$; when oral lesions are the object of the study, the focus is only on cancer of the mouth. ${ }^{7}$

A predominance of the female sex is observed among the data available, as in the present study. ${ }^{1,8-18}$ This fact is characterized by IBGE as feminization of the elderly population, ${ }^{19}$ explained by the differences in survival between the sexes; on average, women live 8 years longer than men. In addition, women show greater fidelity to preventive and educational programs, in addition to making more demands on the outpatient health services than men. ${ }^{20}$

There was no uniformization as regards age groups at the two centers of the research. The most affected age group at BA1 was between 69 and 100 years, which is in agreements with the studies of Ferreira et al ${ }^{13}$ and Carvalho et al. ${ }^{14}$ The group of elderly patients growing most rapidly in Brazil is that of persons aged 80 years and over. ${ }^{21}$ However, Corrêa et al found a greater prevalence of oral lesions in younger elderly patients, as was found in the study conducted at BA2. ${ }^{18}$

The majority of the population in the present study was single, separated, or widowed, which is in agreement with other studies. ${ }^{13,19}$ The data of this study led to the understanding that the chances of women facing the decline in physical and mental capacity without the support of a 
husband are greater, because at BA1, 289 elderly women live without companions compared with 82 elderly men without companions, and at BA2, 114 elderly women compared with 51 elderly men.

The criterion used by the IBGE for classification of race/ ethnicity is self-declaration. However, for this qualification in the record charts/biopsy reports used in this study, there was no way to prove this standardization due to the diversity of ways the documents were filled out. Over half the elderly patients were black/mixed race, proving the miscegenation of the Bahian population. This result contradicts the findings of authors Deboni et $\mathrm{al}^{8}$ and Carvalho et al. ${ }^{14}$ Bahia is the Northeastern State that has the largest number of elderly black people; however, $55.4 \%$ of the elderly Brazilian population registered in PNDA (national survey by household sampling) is white. ${ }^{12}$ Nevertheless, one still perceives a situation of inequality and racial discrimination suffered by the historically underprivileged groups.

In developing countries and in countries with economies in transition, the majority of persons who today are very old continue to work and form part of the informal economy, which commonly deprives them of the benefits and appropriate working conditions and social assistance offered by the formal sector of the economy. ${ }^{22}$ In this study, the minority (35.1\% at BA2 and $33.6 \%$ at BA1) were retired.

When schooling was analyzed, it was verified that the major portion of the elderly were represented by no degree of instruction (39.5\%), followed by patients with incomplete primary school education (37.2\%). Thus, it is concluded that the major portion of the population was characterized by illiterate persons and elderly patients with up to eighth-grade schooling, which demonstrates similarity to other studies, ${ }^{10,13}$ and also converge with the data of PNAD, ${ }^{12}$ but diverges with the study conducted in Iran. ${ }^{17}$

Educational level is an indicator in the characterization of the socioeconomic profile of the population. In the elderly population, the indicator of literacy is considered a thermometer of Brazilian educational policies of the past. Up to the 1950s, primary schooling was still restricted to specific social segments. Therefore, the low mean level of schooling of the study population is a reflection of this unequal access. Although the educational condition for elderly patients has improved over the last few years, the situation of this contingent of the population continues to be most unfavorable and affects the condition of their lives and that of their families. $^{19}$

Both the centers were attended by patients from surrounding cities, corresponding to the rural zone. This situation is a result of the rural exodus that has characterized the process of Brazilian urbanization: migration from small centers to the large cities. ${ }^{23}$ However, it should be pointed out that only 42 biopsy reports contained information about the place of residence and none showed the patients' schooling and lifestyle characteristics. These categories of information are important and should be described on the biopsy reports, because it is another datum to help with the identification of oral disease and to trace groups at risk.
Only in the study conducted at BA1 was information verified on the record charts about smoking and/or alcohol consumption. The majority of the patients were both smokers and alcohol consumers (38.5\%), 21\% of the elderly were smokers only, and $33.5 \%$ of them had neither of these habits of life. These findings referring to the greater increase in smoker and alcohol consumer patients corroborate the findings of Batista et al, ${ }^{1}$ who showed that smoking and alcohol consumption were the most prevalent habits (48.8\%). Dentures were worn by 340 (50.8\%) of the subjects, with complete dentures (73.3\%) being the most prevalent, in agreement with other researchers. ${ }^{2,15,24}$ The large proportion of completely edentulous subjects reflects the history of dentistry over the past 80 years in Brazil, where extractions were indicated by doctors and dentists as a prophylactic measure for systemic diseases based on the theory of focal infection. ${ }^{25}$

The literature depicts a diversity of nomenclature for oral lesions and study methodologies when the object is oral lesions in the elderly, thereby making it difficult to compare data. Therefore, standardization of these criteria is needed to enable better evaluation of the oral health conditions of the elderly.

For oral lesions identified only by clinical exam, at BA2 fibroma (13\%) was the most prevalent, which differs from results by other researchers, ${ }^{10,16,24}$ who identified fibrous hyperplasia as the most prevalent oral lesion in these studies. At BA1, differently from the other center, squamous cell carcinoma (14.5\%) was most prevalent among the oral lesions when it was suspected only in the clinical exam.

When the biopsy was performed, diagnosis of the lesion could be proved by the histopathologic exam. Thus, at BA2 the highest prevalence was shown for fibrous hyperplasia (24\%), followed by squamous cell carcinoma (8.8\%), corroborating the studies conducted by Carvalho et al ${ }^{14}$ and Corrêa et al, ${ }^{18}$ in which fibrous hyperplasia was the most prevalent oral lesion in the biopsies performed in elderly patients. Despite not having data at BA2, it is known that the majority of the elderly patients wear dentures, as a consequence of the era of mutilation in dentistry ${ }^{25}$; therefore, it is suggested that in the elderly, the greater predominance of fibrous hyperplasia is associated with prosthetic trauma. At BA1, squamous cell carcinoma (30.7\%) continued to be the most prevalent lesion by this method of diagnosis, followed by the non-neoplastic lesions (hyperkeratosis and fibrous hyperplasia) and hemangioma. These data emphasize the importance of the correct procedure for the diagnosis of oral lesions, because there is increasing incidence of oral cancer in Brazil, which is ranked the fifth most frequent type of cancer among men and seventh among women ${ }^{26}$; when this lesion is detected early, it presents a higher survival rate than the other types of cancer. $^{27}$

There was no uniformization of anatomic location at the studied centers, despite both centers showing equal frequencies for lesions of the jugal mucosa. In the elderly cared for at BA1, the palate (23.6\%) was the most prevalent location of the lesions, as it was in the study of Hidalgo et al. ${ }^{9}$ This differed from the finding at BA2, where the most prevalent oral location was the alveolar ridge (18\%). 
Epidemiologic studies of a descriptive nature help with evaluation of the oral health of elderly patients; the incidence and prevalence of diseases in the oral mucosa are important parameters for helping with strategies to improve the oral health of this population. However, some of the limitations of this study should be pointed out, such as the faithfulness of the data collected and failures in filling out the record charts and biopsy reports, because the clinical exam is a subjective act and the knowledge of the student/professional is implicit; in addition, different examiners filled out the record charts. After all, these reference centers for oral lesions form part of higher learning institutions, where there is a constant search for the improvement of knowledge and diversity of knowledge and ways to see reality.

The data obtained must not be envisaged as representative of the elderly population in general, because the study was conducted at services whose conclusion obtained must be directed only toward the population assisted. Moreover, many diseases that occur in this are range are diagnosed by their clinical expression (history, signs and symptoms) from observational data and without therapeutic proof. Other factors that deserve emphasis are the possible interferences in the expression of the diseases that translate into greater or less exposure to causal factors, whose prevalence varies geographically.

The change in the population structure gives rise to changes in approach and planning of dental treatments. The increase in the contingent of elderly patients needs adequate support in the public health system, as they may suffer aggravation of their health conditions, frequently connected with aging, such as the accumulation of sequelae of diseases, development of incapacities, and loss of independence and quality of life.

Epidemiologic surveys are used for the evaluation of the oral health of certain populations and are of great importance for the creation of methods to promote health and prevent disease, thereby making it possible to reduce the incidence and evolution of certain diseases.

\section{Conclusion}

In the epidemiologic survey of oral lesions in elderly patients conducted at the centers of reference of public universities in Bahia, Brazil over a period of 8 years, fibrous hyperplasia and squamous cell carcinoma were the oral lesions most frequently diagnosed in the histopathologic exam, despite fibroma and squamous cell carcinoma being more frequently identified in the clinical exam. There was a higher proportion of women than men, and black and elderly patients without companions were the most prevalent sociodemographic data at the centers.

The results of the present study direct dentists toward more careful clinical exam of elderly patients, in addition to the development of educational activities, with emphasis on self-exam for early detection of oral lesions.

Further research is necessary to elucidate some of the findings of this study, in addition to serving as a basis for future analytical studies. The data suggest the need for implementation of a policy of prevention and control of oral lesion in Bahia, to make it feasible to reduce the incidence of new cases and aid in early diagnosis and adequate treatment of oral lesions.

\section{References}

1 Batista ALA, Barbosa ECS, Godoy GP, Catão MHCV, Lins RDAU, Maciel SML. Avaliação das condições de saúde bucal de idosos institucionalizados no município de Campina Grande-PB. Odontol Clín Ciente 2008;7(3):203-208

2 Isolam CP. Saúde oral dos idosos que frequentam o convento Santo Antônio: centro, Rio de Janeiro [dissertação]. Rio de Janeiro, Brazil: Universidade Veiga de Almeida; 2006

3 Silva EMM, Barão VAR, Santos DM, Delibem JA, Ribeiro ACP, Galgo AKG. Principais alterações e doenças bucais que acometem o paciente geriátrico-revisão da literatura. Odonto 2011;19(37): 39-47

4 Moreira RdaS, Nico LS, Tomita NE, Ruiz T. Oral health of Brazilian elderly: a systematic review of epidemiologic status and dental care access. Cad Saude Publica 2005;21(6):1665-1675

5 R Development Core Team. R: A language and environment for statistical computing. Vienna, Austria: R Foundation for Estatística Compotinha; 2008. Available at: http://www.r-project.org. Accessed September 2, 2011

6 Barnes L, Everson JW, Reich art P, Saransk D. World Health Organization Classification of Tumors. Pathology and Genetics of Head and Neck Tumors. Lyon, France: IARC Press; 2005

7 Henrique RB, Bazaga M Jr, Araújo VC, Junqueira JLC, Furuse C. Prevalência de alterações da mucosa bucal em indivíduos adultos da população de Uberaba, Minas Gerais. RGO 2009;57(3): 261-267

8 Deboni MCZ, Traina AA, Trindade IK, Rocha EMV, Teixeira VCB, Takahashi A. Levantamento retrospectivo dos resultados dos exames anatomopatológicos da disciplina de cirurgia da FOUSP -SP. RPG Rev Pos-Grad 2005;12(2):229-233

9 Hidalgo SH, Diaz MJR, French NF. Alterações buçales em pacientes geriátricos portadores de próteses totais em das áreas de saluda. Arché Méd Camaguey 2005;9(6)

10 Mesas AE, Andrade SM, Cabrera MAS. Condições de saúde bucal de idosos de comunidade urbana de Londrina, Paraná. Rev Bras Epidemiol 2006;9(4):471-480

11 Mujica V, Rivera H, Carrero M. Prevalence of oral soft tissue lesions in an elderly Venezuelan population. Med Oral Patol Oral Cir Bucal 2008;13(5):E270-E274

12 Instituto Brasileiro de Geografia e Estatística (IBGE). Pesquisa Nacional por Amostra de Domicílios de 2003 a 2009. Available at: http://www.ibge.gov.br. Accessed October 5, 2010

13 Ferreira RC, Magalhães CS, Moreira AN. Oral mucosal alterations among the institutionalized elderly in Brazil. Braz Oral Res 2010; 24(3):296-302

14 Carvalho MdeV, Iglesias DPP, do Nascimento GJ, Sobral APV. Epidemiological study of 534 biopsies of oral mucosal lesions in elderly Brazilian patients. Gerodontology 2011;28(2):111-115

15 Jainkittivong A, Aneksuk V, Langlais RP. Oral mucosal conditions in elderly dental patients. Oral Dis 2002;8(4):218-223

16 Espinoza I, Rojas R, Aranda W, Gamonal J. Prevalence of oral mucosal lesions in elderly people in Santiago, Chile. J Oral Pathol Med 2003;32(10):571-575

17 Mozafari PM, Dalirsani Z, Delavarian Z, et al. Prevalence of oral mucosal lesions in institutionalized elderly people in Mashhad, Northeast Iran. Gerodontology 2012;29(2):e930 e934

18 Corrêa L, Frigerio MLMA, Sousa SC, Novelli MD. Oral lesions in elderly population: a biopsy survey using 2250 histopathological records. Gerodontology 2006;23(1):48-54 
19 Instituto Brasileiro de Geografia e Estatística (IBGE). Perfil dos idosos responsáveis pelos domicílios no Brasil 2000. Rio de Janeiro, Brazil:2002

20 Parahyba MI, Veras R. Sociodemographic differentials in the functional decline among the elderly in Brazil. Cien Saude Colet 2008;13(4):1257-1264

21 Organização das Nações Unidas. Plano de ação internacional contra o envelhecimento, 2002. Tradução Arlene Santos. Brasília: Secretaria Especial dos Direitos Humanos; 2007

22 Organização Mundial de Saúde (OMS). Envelhecimento ativo: uma política de saúde / World Health Organization; tradução Suzana Gontijo. Brasília: Organização Pan-Americana da Saúde; 2005

23 Martine G, Camaro AM, Neupert R, Beltrão K. A urbanização no Brasil: retrospectiva, componentes e perspectiva. Para a Década de
90: Prioridades e Perspectivas de Políticas Públicas. Brasília: IPEAIPLAN; 1990

24 Dundar N, Ilhan Kal B. Oral mucosal conditions and risk factors among elderly in a Turkish school of dentistry. Gerontology 2007; 53(3):165-172

25 Scelza MFZ, Rodrigues C, Silva VS, Faria LCM, Câmara V, Scleza Neto P. Saúde Bucal dos pacientes do programa interdisciplinar de Geriatria e Gerontologia da UFF. Rev Bras Odontol 2001;58(5):351-354

26 Brasil. Ministério da Saúde. Instituto Nacional de Câncer. Estimativa 2010: incidência de câncer no Brasil/Instituto Nacional de Câncer. Rio de Janeiro, Brazil: INCA; 2009

27 Mashberg A, Samit AM. Early detection, diagnosis, and management of oral and oropharyngeal cancer. CA Cancer J Clin 1989; 39(2):67-88 